\title{
APRESIASI PETANI TERHADAP TEKNOLOGI DAN PENYULUHAN PERTANIAN DALAM PENINGKATAN PRODUKSI PADI DI JAWA BARAT
}

\section{FARMERS APPRECIATION ON TECHNOLOGY AND AGRICULTURAL EXTENSION FOR INCREASING RICE PRODUCTION}

\author{
Trisna Subarna \\ Peneliti Madya Pada Bappeda Provinsi Jawa Barat \\ Jl. Ir. H. Juanda No. 287 Bandung \\ e-mail: mjlk_trisna@yahoo.co.id \\ Dikirim: 10 Maret 2013; direvisi: 14 April 2013; disetujui: 19 Juni 2013
}

\begin{abstract}
Abstrak
Penelitian apresiasi petani terhadap teknologi dan penyuluhan pertanian dalam peningkatan produksi padi telah dilaksanakan pada Bulan Januari sampai Mei 2012 di 10 kabupaten sentra produksi padi di Jawa Barat. Penelitian dilaksanakan dengan metoda survey dengan total responden 120 petani. Penelitian ini bertujuan untuk mengetahui apresiasi petani terhadap teknologi dan penyuluhan dalam meningkatkan produksi padi. Hasil penelitian menunjukkan: (1) Teknologi yang berperan penting dalam peningkatan produksi padi adalah: (a) teknologi peningkatan kesuburan lahan, (b) teknologi meminimalkan kehilangan hasil panen, dan (c) varietas unggul baru. (2) Teknologi yang diapresiasi tinggi kinerjanya oleh petani adalah; varietas unggul baru, dan peningkatan kesuburan lahan, sedangkan teknologi kehilangan hasil panen diapresiasi kurang, sehingga ketiga teknologi tersebut merupakan faktor yang sangat berperan dalam peningkatan produksi padi. (3) Prequensi kehadiran penyuluh mempunyai peranan penting dalam upaya peningkatan produksi padi, tetapi kinerjanya diapresiasi rendah. Implikasi hasil penelitian ini adalah: (a) Diperlukan kebijakan Pemerintah Daerah melaui Peraturan Daerah untuk meningkatkan kesuburan lahan melalui pemanfaatan jerami, dan kebijakan penambahan jumlah serta fasilitas penyuluh pertanian. (b) Penyediaan varietas unggul baru melalui pengembangan dan pembinaan penangkar benih serta meningkatkan peranan Balai Benih Padi Jawa Barat, dan (c) meminimalkan kehilangan hasil panen melalui penerapan kelembagaan jasa panen dan penerapan Power Tresherr.
\end{abstract}

Kata Kunci: teknologi, penyuluhan pertanian.

\begin{abstract}
Study of farmers appreciation on technology and agricultural extension for increasing rice production has been carried out in January to May 2012 in ten rice producers districts in West Java. Research conducted by survey method with a total of 120 farmer respondents. The objective of the study were to identify and implement agricultural extension technology that can increase rice production. The results of this study showed: (1) The important to increase rice production in West Java includes: (a) soil fertility, technology increased, (b) minimize in lost crops technology, (c) new varieties. (2) The technology was mostly appreciated by farmer was new high yield varieties and soil fertility improvement technology, while minimizely yield lost tehnology otherwise. It was thesefore,both tehnologies is on consider as importantce in increasing rice yield.(3) outreach activities that have an important role in increasing rice production is frequenti agricultural extension in the presence of farmers, which was low-appreciated by the farmers. So that the instructor's presence at the farm level need to be improved. The implications of this strudy are; (a) a local regulation government policy to improve soil fertility through the use of straw, and policies as well as increasing the number of agricultural extension facilities. (b) the provision of new varieties through the development of breeder seed and coaching as well as enhancing the role of West Java Rice Seed Center, and (c) minimize the loss of crop yields through the application of institutional services and application of Power Tresher.

Keywords: technology, agricultural extension
\end{abstract}

\section{PENDAHULUAN}

Berbagai kebijakan untuk meningkatkan produksi padi, seperti: pembangunan sarana irigasi, pengadaan varietas, fasilitasi sarana produksi, alat mesin pertanian, kredit modal usahatani, dan pembinaan kelembagaan usahatani telah dilakukan oleh Pemerintah Provinsi Jawa Barat. Kebijakan tersebut pada dasarnya ditujukan untuk meningkatkan luas panen dan produktivitas padi, yang pada akhirnya dapat meningkatkan produksi padi. Pada tahun 2010 produksi padi Provinsi Jawa Barat mencapai 11.737.070 ton gabah kering giling (GKG), atau naik 3,66 persen dibanding tahun 2009, 
kenaikan tersebut disebabkan oleh peningkatan luas panen sebesar 4,48 persen dari 1.950.203 hektar tahun 2009 menjadi 2.037.657 hektar tahun 2010, sedangkan produktivitas mengalami penurunan sebesar 0,79 persen yaitu dari 58,06 kuintal per hektar tahun 2009 menjadi 57,60 kuintal per hektar pada tahun 2010 (BPS,2011).

Produksi padi pada tahun 2010 tersebut di atas tidak mencapai target yang telah ditetapkan sebesar 5,00 persen, sehingga menjadi permasalahan yang serius untuk mencapai target surplus beras yang ditetapkan pemerintah untuk Jawa Barat sebesar 2,9 juta ton pada tahun 2014. Kenaikan produktivitas seharusnya lebih tinggi dibanding dengan kenaikan luas panen, namun kenyataannya pada tahun 2010 produktivitas padi di Jawa Barta turun 0,79 persen dibanding tahun 2009.

Penurunan produktivitas padi tersebut diduga disebabkan oleh rendahnya penggunaan teknologi di tingkat petani, yang diakibatkan oleh terdapat beberapa pembatas diantaranya ketersediaan dan kesuburan lahan, ketersediaan dan kualitas infrastruktur uasahatani (irigasi, jalan), iklim, kondis sosial dan ekonomi petani, dan kelembagaan pendukung usahatani. Sehingga untuk meminimalkan pembatas tersebut menurut Pantjar Simatupang dan Nizwar Syafa'at, (2002) diperlukan teknologi dan penerapannya di tingkat petani. Namun demikian karena pada pelaksanaan peningkatan produksi padi yang dilakukan melalui Sekolah Lapang Pengelolaan Tanaman Terpadu (SLPTT) padi di Jawa Barat terdiri atas beberapa komonen teknologi, maka diperlukan teknologi dan metoda penyuluhan yang sangat diperlukan oleh petani.

\section{METODE PENELITIAN}

Penelitian ini dilaksanakan pada bulan Januari sampai Mei 2012 di 10 Kabupaten sentra produksi padi Jawa Barat yaitu Kabupaten Karawang, Subang, Indramayu, Cirebon, Majalengka, Ciamis, Tasikmalaya, Garut, Cianjur dan Sukabumi, dengan menggunakan metoda survey dan diskusi. Penentuan lokasi dari masing-masing kabupaten dipilih satu lokasi/kelompok tani yang telah dibina Dinas Pertanian melalui Sekolah Lapang Pengelolaan Tanaman Terpadu (SLPTT)

Data yang diperlukan berupa data primer yang dikumpulkan melalui diskusi kelompok terfokus (focus group discussion - FGD), melibatkan petani, penyuluh, dan unsure pendaping serta petugas dinas pertanian Pertanian Kabupaten sampel. Data primer juga dikumpulkan dari petani sampel dari peserta SLPTT, sejumlah 10 orang per kelompok, sehingga jumlah responden sebanyak 120 orang.

1. Untuk menentukan tingkat pentingnya teknologi dilakukan dengan penilaian oleh responden terhadap kinerja teknologi terhadap produksi padi berdasarkan pengalaman, analisis dan prediksi petani dalam skala 1 sampai dengan 5, dimana 1 adalah penilaian terendah dan 5 penilaian tertinggi, dengan kriteria sebagai berikut:

\section{Tabel 1. Kriteria Tingkat Kepentingan}

\begin{tabular}{lll}
\hline No & \multicolumn{1}{c}{ Nilai CSI } & \multicolumn{1}{c}{ Kriteria CSI } \\
\hline 1 & $4,10-5,00$ & Sangat Penting \\
2 & $3,10-4,00$ & Penting \\
3 & $2,10-3,00$ & Cukup Penting \\
4 & $1,10-2,00$ & Kurang \\
& & Penting \\
5 & $0,00-1,00$ & Tidak Penting \\
\hline
\end{tabular}

2. Untuk menganalisis apresiasi petani terahadap teknologi dan penyuluhan dalam peningkatan produksi padi digunakan pendekatan Customer Satisfaction Index (CSI) atau tingkat kepuasan petani (IKP) yang dilakukan dengan menilai tingkat kepentingan teknologi dan kinerjanya di lapangan, analisis ini menggunakan pendekatan CSI (Aritonang, 2005 dalam Rahmat Hendayana, 2010). Langkah penerapan CSI akan dilakukan sebagai berikut:

(a) Pertama, menentukan Mean Importance Score (MIS). Nilai ini diperoleh dari perhitungan rata-rata kepentingan tiap petani.

$$
\text { MIS }=\frac{\left[\sum_{i=1}^{n} Y_{i}\right]}{n}
$$

Dalam hal ini $\mathrm{n}=$ jumlah petani dan $\mathrm{Y}_{\mathrm{i}}=$ nilai kepentingan variabel faktor penentu peningkatan produksi padi Y ke i.

(b) Kedua, menghitung Weight Factors (WF). Bobot ini merupakan persentase nilai MIS per variabel faktor penentu peningkatan produksi padi terhadap total MIS seluruh variabel faktor penentu peningkatan produksi padi.

$$
\mathrm{WF}=\frac{\mathrm{MIS}_{\mathrm{i}}}{\sum_{i=1}^{p} \mathrm{Vi}} \times 100 \%
$$

Dalam hal ini $\mathrm{p}$ adalah kepentingan variabel faktor penentu peningkatan produksi padi ke $\mathrm{p}$

(c) Ketiga, menghitung Weight Score (WS). Bobot ini merupakan perkalian antara WF dengan rata-rata tingkat kepuasan $(\mathrm{X})$ atau Means Stisfaction Score (MSS).

$$
\mathrm{WSi}=\mathrm{Wfi} \mathrm{x} \text { MSS }
$$

(d) Keempat, menentukan Customer Satisfaction Indeks (CSI) atau Indeks Kepuasan Petani (IKP). 


$$
\mathrm{CSI}=\frac{\sum_{i=1}^{p} \text { WSI }}{\mathrm{HS}} \times 100 \%
$$

Dalam hal ini, $p=$ variabel faktor penentu peningkatan produksi padi ke $\mathrm{p}$ dan HS = Highest scale) atau skala maksimum yang digunakan.

Pada umumnya bila nilai $\mathrm{CSi}>50 \%$ dikatakan bahwa petani sudah merasa puas terhadap faktor penentu peningkatan produksi padi yang dilakukan. Sebaliknya bila $<50 \%$ petani belum puas.

Nilai CSI dalam pengkajian ini mengacu pada kriteria PT Sucofindo yang sudah coba diimplementasikan Oktaviani dan Suryana (2006), sebagai berikut:

\section{Tabel 2. Kriteria Nilai Customer Satisfaction Index $(\mathrm{CSI} / \mathrm{IKP})$}

\begin{tabular}{lll}
\hline No & \multicolumn{1}{c}{ Nilai CSI } & Kriteria CSI \\
\hline 1 & $0,81-1,00$ & Sangat puas \\
2 & $0,66-0,80$ & Puas \\
3 & $0,51-0,65$ & Cukup Puas \\
4 & $0,35-0,50$ & Kurang Puas \\
5 & $0,00-0,34$ & Tidak Puas \\
\hline
\end{tabular}

Sumber: Ihsani (2005) dalam Hendayana (2010)

\section{HASIL DAN PEMBAHASAN}

\section{Peranan Teknologi dalam Peningkatan Produksi Padi}

Hasil analisis terhadap teknologi usahatani padi yang di terapkan pada pelaksanaan Sekolah Lapang Pengelolaan Tanaman Terpadu (SLPTT) di Jawa Barat diperoleh delapan teknologi yang berperan penting dalam peningkatan produksi padi yaitu; (a) alat mesin pertanian, (b) cara tanam, (c) kehilangan hasil, (d) kesuburan lahan, (e) pemupukan berimbang, (f) pengaturan pola tanam, (g) pengendalian OPT, dan (h) Varietas Unggul Baru (VUB).

Hasil analisis ini juga menunjukkan peranan teknologi dalam meningkatkan produksi padi di Jawa Barat berperan cukup tinggi, yang ditunjukan oleh rata-rata skor kepentingan sebesar 3,07 (katagori cukup tinggi) dari skor 5,00 yang diharapkan (Tabel 3 ), atau 61,40 persen upaya peningkatan produksi padi ditentukan oleh delapan teknologi tersebut di atas, sedangkan sisanya dipengaruhi oleh faktor lain diluar hasil analisis.

\begin{tabular}{|c|c|c|}
\hline Instrumen & Skor & Katagori \\
\hline Alat mesin pertanian & 2.83 & Cukup Penting \\
\hline Cara tanam & 2.70 & Cukup Penting \\
\hline Kehilangan hasil & 3.87 & Penting \\
\hline $\begin{array}{l}\text { 4. Peningkatan } \\
\text { kesuburan lahan }\end{array}$ & 3.43 & Penting \\
\hline $\begin{array}{l}\text { 5. Pemupukan } \\
\text { berimbang }\end{array}$ & 2.55 & Cukup Penting \\
\hline Pola tanam (IP) & 2.53 & Cukup Penting \\
\hline Pengendalian OPT & 3.03 & Cukup Penting \\
\hline $\begin{array}{l}\text { 8. Varietas Unggul } \\
\text { Baru }\end{array}$ & 3.65 & Penting \\
\hline Rata-rata & 3,07 & Cukup Penting \\
\hline
\end{tabular}

Tabel 3.Tingkat Kepentingan Teknologi Usahatani Padi di Jawa Barat $(n=120)$

Dari delapan teknologi tersebut yang sangat berperan penting dan dibutuhkan oleh petani saat ini adalah VUB, teknologi meminimalkan kehilangan hasil dan teknologi peningkatan kesuburan lahan., sedangkan teknologi lainnya berada pada katagori cukup tinggi.

\section{Peranan Penyuluhan dalam Peningkatan Produksi Padi}

Penyuluhan pertanian mempunyai peran yang sangat tinggi dalam peningkatan produksi padi, terutama dalam penyebaran dan penerapan teknologi, sehingga teknologi dan penyuluhan merupakan dua aspek yang tidak dapat dipisahkan. Hasil analisis menunjukkan penyuluhan merupakan faktor cukup penting dalam peningkatan produksi padi dengan skor rata-rata 2,91 dari skor harapan 5,00 (Tabel 4).

Tabel 4.Tingkat Kepentingan Penyuluhan dalam Peningkatan Produksi Padi Di Jawa Barat ( $=120)$

\begin{tabular}{rlrl}
\hline \multicolumn{1}{c}{ Instrumen } & Skor & \multicolumn{1}{c}{ Katagori } \\
\hline 1. Waktu Penyuluhan & 2.83 & Cukup Penting \\
2. Frequensi Penyuluhan & 3.41 & Penting \\
3. Tempat Penyuluhan & 2.67 & Cukup Penting \\
4. Materi sesuai kebutuhan & 2.72 & Cukup Penting \\
Rata-rata & 2.91 & Cukup Penting \\
\hline
\end{tabular}

Intensitas pelaksanaan tatap muka antara penyuluh dengan petani (Frequensi penyuluhan) yang dikenal dengan Sistem Latihan dan Kunjungan (LAKU) merupakan sistem kerja penyuluhan pertanian saat ini masih dibutuhkan oleh petani. Hasil analisis menunjukkan frequensi penyuluhan berada pada tingkat yang sangat diperlukan oleh petanin saat ini dengan katagori penting (Tabel 2). Hal ini sesuai dengan beberapa hasil study diantaranya menurut Sultan Mawardi (2005) bahwa kegiatan penyuluhan melalui tatap muka memberikan kontribusi besar terhadap peningkatan produksi pertanian.

Implikasi kebijakan di bidang Penyuluhan yang perlu diterapkan adalah meningkat intensitas kunjungan petani kepada kelompok tani 
binaannya secara terjadual dan teratur serta pengawasan yang intensif dari pejabat yang berwenang agar pelaksanaannya dapat berjalan dengan baik.

\section{Apresiasi Petani terhadap Teknologi}

Dari delapan teknologi penting dalam peningkatan produksi padi di Jawa barat terdapat tiga teknologi yang diapresiasi tinggi oleh petani berupa indeks kepuasan petani (IKP) dalam katagori puas yaitu dari Varietas Unggul Baru, Peningkatan Indeks Pertanaman, dan pengendalian OPT, sedangkan teknologi penanganan kehilangan hasil diapresiasi dengan IKP kurang puas ( Tabel 5).

Tabel 5. Tingkat Kepuasan Petani Terhadap Teknologi Usahatani Padi di jawa Barat $(n=-120)$

\begin{tabular}{|c|c|c|c|}
\hline \multicolumn{2}{|r|}{ Instrumen } & $\begin{array}{c}\text { Indeks Kepuasan } \\
\text { Petani (IKP) }\end{array}$ & $\begin{array}{c}\text { Katagor } \\
\text { i IKP }\end{array}$ \\
\hline & $\begin{array}{l}\text { Alat mesin } \\
\text { pertanian }\end{array}$ & 0.57 & $\begin{array}{l}\text { Cukup } \\
\text { Puas }\end{array}$ \\
\hline 2. & Cara tanam & 0.63 & $\begin{array}{l}\text { Cukup } \\
\text { Puas }\end{array}$ \\
\hline 3. & Kehilangan hasil & 0.45 & $\begin{array}{l}\text { Kurang } \\
\text { Puas }\end{array}$ \\
\hline & $\begin{array}{l}\text { Peningkatan } \\
\text { kesuburan lahan }\end{array}$ & 0.73 & $\begin{array}{l}\text { Cukup } \\
\text { Puas }\end{array}$ \\
\hline 5. & $\begin{array}{l}\text { Pemupukan } \\
\text { berimbang }\end{array}$ & 0.67 & $\begin{array}{l}\text { Cukup } \\
\text { Puas }\end{array}$ \\
\hline 6. & Pola tanam (IP) & 0.61 & Puas \\
\hline 7. & Pengendalian OPT & 0.73 & Puas \\
\hline & $\begin{array}{l}\text { Varietas Unggul } \\
\text { Baru }\end{array}$ & 0.71 & Puas \\
\hline Rate & rata & 0.64 & $\begin{array}{l}\text { Cukup } \\
\text { Puas }\end{array}$ \\
\hline
\end{tabular}

Teknologi yang diapresiasi puas oleh petani menunjukkan kinerja teknologi tersebut diyakini dapat meningkatkan produksi padi. Sedangkan teknologi yang diapresiasi kurang puas menujukkan teknologi yang diitroduksikan belum menyelesaikan maslah dalam peningkatan produksi padi.

\section{Teknologi Penanganan Kehilangan Hasil Panen}

Teknologi penanganan hasil panen merupakan teknologi yang penting dalam peningkatan produksi padi, namun teknologi yang diintroduksikan saat ini dinilai belum tepat sehingga diapresiasi rendah oleh petani. Penggunaan sabit bergerigi, dan alas terpal, yang diintroduksikan kepada petani belum mengoptimalkan upaya mengurangi kehilangan hasil. Masih tingginya tingkat kehilangan hasil dalam penggunaan teknologi sabit bergerigi disebabkan bentuknya yang kurang lengkung, sedangkan terpal ukuran 2X3 masih menyebabkan tingginya gabah tercecer dalam proses perontokan. Kedua teknologi ini perlu dilakukan rekayasa sesuai dengan kehendak petani.

Penggunaan power tresher sebagai teknologi dintroduksikan ke petani saat ini belum dapat menyelesaikan masalah dalam kehilangan hasil, yang disebabkan oleh belum siapnya kelembagaan pemanen. Tidak terkendalinya pemanen di sentra produksi padi menyebabkan power treser yang disediakan pemerintah tidak dipakai oleh petani. Sehingga untuk penggunaan power treser diperlukan kelembagaan pemanen yang sesuai dengan kondisi setempat. Pengembangan pemanenan padi dengan sistem kelompok, usaha pelayanan jasa alsintan (UPJA) dalam mengembangkan kelompok jasa perontok, diharapkan akan mendorong tumbuhnya bengkel-bengkel alsintan yang membuka lapangan kerja baru di pedesaan (Setyono, 2001).

\section{Varietas Unggul Baru (VUB).}

Varietas Unggul Baru (VUB) merupakan teknologi yang sangat mempengaruhi produksi padi, dan dipreseiasi tinggi oleh petani dengan tingkat Indeks Kepuasan Petani (IKP) berada pada katagori puas. Hasil analisis menunjukkan bahwa VUB berperan penting dalam upaya peningkatan produksi padi di Jawa Barat. Hal ini sesuai dengan hasil penelitian Badan Litbang Pertanian (2007), Hapsah (2005) dan Imran et al. (2003), bahwa varietas merupakan salah satu teknologi yang berperan penting dalam peningkatan kuantitas dan kualitas produk pertanian termasuk padi. Menurut Baehaki (2001) bahwa varietas sebagai salah satu komponen produksi telah memberikan sumbangan sebesar $56 \%$ dalam peningkatan produksi padi.

\section{Pola tanam (IP)}

Peningkatan produksi padi masih dapat diupayakan, melalui, peningkatan indeks pertanaman (IP) dan produktivitas. Di beberapa daerah di Jawa Barat, sebagian petani mengusahakan padi lima kali dalam 2 tahun (IP 250) dan di lokasi tertentu bahkan tiga kali per tahun (IP 300) karena air tersedia sepanjang musim. Program intensifikasi padi selama ini terutama diarahkan pada lahan irigasi dengan suplai air yang terjamin. Meskipun tidak dianjurkan, lahan sawah dengan IP padi 200 dapat ditingkatkan menjadi IP padi 300 apabila air hujan atau air irigasi mencukupi (Hasanuddin, 2005).

Introduksi teknologi pola tanam di Jawa barat diapresiasi baik oleh petani dengan IKP pada katagori cukup puas. Kondisi ini menunjukkan peningkatan produksi padi di jawa barat dapat dilakukan melalui peningkatan IP dari rata-rata untuk mendongkrak IP padi antara 150 pada lahan irigasi pedesaan, dan irigasi sederhana menjadi IP 250 sampai 300. artinya, akan ada tambahan panen 1-3 kali di lahan sawah.

\section{Pengendalian OPT}

Pelaksanaan program pengendalian hama terpadu (IPM) (Integreted Pest Management) merupakan langkah yang sangat strategis dalam kerangka tuntutan tersebut, karena aman dikonsumsi, menjaga kelestarian lingkungan, serta pengelolaan sumberdaya alam yang berkelanjutan. Salah satu 
komponen pengendalian hama terpadu (PHT) ini yang sesuai untuk menunjang pertanian berkelanjutan adalah pembangunan pertanian secara hayati karena pengendalian ini lebih selektif (tidak merusak organisme yang berguna dan manusia) dan lebih berwawasan lingkungan (Mulyaman, 2008). Pengendalian OPT secara biologi dengan penggunaan musuh alami dianggap mempunyai prospek yang bagus, karena disamping tersedia di alam, juga ramah terhadap lingkungan.

Introduksi pengendalian OPT padi melalui IPM mendapat respon yang baik dari petani yang ditunjukkan oleh IKP dengan katagori puas. Artinya teknologi yang diintroduksikan dapat meningkatkan produksi padi. Hal ini sesuai dengan pendapat Saptana at al., (2010) bahwa petani sebagai pelaku utama kegiatan pertanian menyadari bahwa dengan menggunakan pestisida sintetis untuk pengendalian dapat mengakibatkan eksploitasi hama. Disamping dapat menekan populasi OPT (walaupun dalam jangka panjang), petani meyakini modal yang telah dikeluarkan untuk mengendalikan OPT secara kimiawi cukup besar..

\section{Teknologi Kesuburan Lahan}

Sumber daya lahan merupakan salah satu faktor yang sangat menentukan keberhasilan suatu sistem usaha pertanian, karena hampir semua usaha pertanian berbasis pada sumber daya lahan. Tingkat kesuburan lahan sawah ditentukan oleh kadar hara dalam tanah atau status hara tanah. Pemakaian pupuk anorganik terus-menerus dan takarannya yang selalu ditingkatkan membuat kualitas tanah terdegradasi. Akibatnya, pemupukan tidak bisa lagi menaikkan hasil. Pemakaian pupuk anorganik terus-menerus dan takarannya yang selalu ditingkatkan membuat kualitas tanah terdegradasi (Swastika, at al, 2007).

Kenyataannya dilapangan kualitas lahan sawah di Jawa Barat telah banyak terdegregasi, sehingga kesuburan lahannya berkurang, dan memerlukan pupuk an-organik dengan dosis tinggi. Aplikasi teknologi dengan pemanfaatan jerami dan pemupukan berimbang untuk kesuburan lahan telah diapresiasi petani dengan IKP cukup puas, artinya teknologi peningkatan kesuburan lahan tersebut sudah mebawa dampak peningkatan kesuburan lahan. Hal ini sesuai dengan pendapat Karama et al. (1990) dalam Suhartatik dan Sismiyati, 2000) bahwa satu upaya yang dapat ditempuh untuk memperbaiki kondisi kesuburan lahan sawah.

\section{Apresiasi Petani terhadap Pelaksanaan Penyuluhan}

Kegiatan penyuluhan di lapangan secara keseluruhabn di apresiasi petani dengan IKP cukup puas, kegiatan frequensi penyuluhan diapresiasi kurang puas oleh petani (Tabel 6). IKP terhadap frequensi penyuluhan yang kurang puas menunjukkan rendahnya kunjungan penyuluh ke petani, atau setidaknya terjadi perubahan frequensi kunjungan yang aslnya sering menjadi sangat jarang. Kondisi ini menunjukkan masih diperlukannya penyuluh oleh petani.

Tabel 6. Tingkat Kepuasan Petani Terhadap Pelaksanaan Penyuluhan di Jawa Barat $(\mathbf{n = 1 2 0})$

\begin{tabular}{|c|c|c|c|}
\hline & Instrumen & $\begin{array}{c}\text { Indeks Kepuasan } \\
\text { Petani (IKP) } \\
\end{array}$ & $\begin{array}{c}\text { Katagori } \\
\text { IKP }\end{array}$ \\
\hline & $\begin{array}{l}\text { Waktu } \\
\text { Penyuluhan }\end{array}$ & 0.47 & $\begin{array}{l}\text { Cukup } \\
\text { Puas }\end{array}$ \\
\hline 2. & $\begin{array}{l}\text { Frequensi } \\
\text { Penyuluhan }\end{array}$ & 0.49 & $\begin{array}{l}\text { Kurang } \\
\text { Puas }\end{array}$ \\
\hline 3. & $\begin{array}{l}\text { Tempat } \\
\text { Penyuluhan }\end{array}$ & 0.54 & $\begin{array}{l}\text { Cukup } \\
\text { Puas }\end{array}$ \\
\hline 4. & $\begin{array}{l}\text { Materi sesuai } \\
\text { kebutuhan }\end{array}$ & 0.55 & $\begin{array}{l}\text { Cukup } \\
\text { Puas }\end{array}$ \\
\hline 5. & Rata-rata & 0.51 & $\begin{array}{l}\text { Cukup } \\
\text { Puas }\end{array}$ \\
\hline
\end{tabular}

Rendahnya IKP prequensi kunjungan penyuluh ke petani, disebabkan oleh; (a) berkurangnya jumlah penyuluh, (b) kurangnya fasilitas bagi penyuluh, dan (c) kurangnya informasi teknologi untuk penyuluhan pertanian. Keadaan tersebut menurut Rajaguguk (2011) terjadinya perubahan kelembagaan penyuluhan sejak penerapan otonomi daerah pada tahun 2000, system penyuluhan pertanian mengalami perubahan dari institusi pusat menjadi otonom, sehingga memberikan dampak terhadap kinerja penyuluhan pertanian secara mendasar dan bervariasi antar daerah. Disamping itu menurut Sulton Mawardi (2005), kegiatan penyuluhan pertanian mengalami beberapa persoalan, antara lain:

1. Kelembagaan penyuluhan pertanian sering berubah-ubah, sehingga kegiatannya sering mengalami masa transisi. Kondisi ini menyebabkan penyuluhan pertanian di lapangan sering terkatung-katung dan kurang berfungsi. Semangat kerja para Penyuluh Pertanian Lapangan (PPL), yang status kepegawaiannya tidak pasti, juga menurun.

2. Dibandingkan dengan kebutuhan, jumlah PPL yang ada kurang mencukupi, demikian pula kualitas dan kapasitasnya.

3. Ketersediaan dan dukungan informasi pertanian (teknologi, harga pasar, kesempatan berusaha tani, dsb.) yang ada di BPP sangat terbatas, atau bahkan tidak tersedia.

\section{SIMPULAN}

1. Teknologi yang mempunyai peranan penting dan diperlukan dalam upaya peningkatan produksi padi di Jawa Barat saat ini adalah: (a) teknologi peningkatan kesuburan lahan, (b) teknologi meminimalkan kehilangan hasil panen, (c) varietas unggul baru.

2. Teknologi yang penting dan sangat diapresiasi kinerjanya oleh petani adalah VUB, sedangkan teknologi kehilangan hasil panen kinerjanya diapresiasi kurang, sehingga kedua teknologi 
tersebut merupakan faktor yang sangat berperan dan diperlukan dalam peningkatan produksi padi.

3. Teknologi peningkatan kesuburan lahan merupakan teknologi yang dinilai penting dan diperlukan saat ini dalam meningkatkan produksi padi yang kinerjanya cukup diapresiasi oleh petani, sehingga kinerja dari teknologi ini perlu ditingkatkan.

4. Komponen penyuluhan yang mempunyai peranan penting dalam upaya peningkatan produksi padi adalah prequensi kehadiran penyuluh, dan saat ini kinerjanya diapresiasi rendah oleh petani

5. Dalam upaya peningkatan produksi padi di Jawa Barat diperlukan: (a) peningkatan teknologi kesuburan lahan dengan pemanfaatan jerami hasil panen melalui Peraturan Daerah atau Keputusan Bupati/Walikota, (b) penyediaan Vareietas Unggul Baru melalui pengembangan, pembinaan penangkar benih di tingkat kelompok tani dengan meningkatkan peranan Balai Benih Padi Pemerintah Provinsi Jawa Barat, dan (3) peningkatan penerapan teknologi dan kelembagaan untuk meminimalkan hasil panen melalui penerapan kelembagaan jasa panen dan penerapan Power Tresher, (4) meningkatkan preguensi interaksi penyuluh pertanian dengan petani atau kelompok tani melalui penambahan jumlah penyuluh dan penambahan biaya operasional penyuluh pertanian lapangan baik dari dana Pemerintah Pusat maupun dari Pemerintah Daerah.

\section{DAFTAR PUSTAKA}

Badan Litbang Pertanian. 2007. PTT Padi Sawah. Pedoman Umum. Badan Penelitian dan Pengembangan Pertanian Departemen Pertanian.

Baehaqi, W.A. 2009 Analisis Kualitas Pelayanan Jasa Terhadap Kepuasan Nasabah Dengan Metode Importance Performance Analysis. http://eprints.undip.ac.id/2868/

BPS, 2011. Jawa Barat dalam Angka, Biro Pusat Statistik.

Hapsah, M.D. 2005. Potensi, Peluang, dan Strategi Pencapaian Swasembada Beras dan Kemandirian Pangan Nasional. Hal. 55-70. Dalam B. Suprihatno et al. (Ed.) Inovasi Teknologi Padi Menuju Swasembada Beras Berkelanjutan. Buku Satu. Balitbangtan, Badan Litbang Pertanian.

Hasanuddin, A. 2005. Peranan proses sosialisasi terhadap adopsi varietas unggul padi tipe baru dan pengelolaannya.Lokakarya Pemuliaan Partisipatif dan Pengembangan Varietas Unggul Tipe Baru (VUTB). Sukamandi 2005. Hapsah, M.D. 2005. Potensi, Peluang, dan
Strategi Pencapaian Swasembada Beras dan Kemandirian Pangan Nasional. Hal. 55-70. Dalam B. Suprihatno et al. (Ed.) Inovasi Teknologi Padi Menuju Swasembada Beras Berkelanjutan. Buku Satu. Balitbangtan, Badan Litbang Pertanian.

Hendayana Rahmat, 2010. Pengkajian Strategi Pendampingan Sl-Ptt Padi Yang Efektif Mendukung Swasembada Beras Berkelanjutan. Proposal : Kegiatan Kompetitif. Balai Besar Pengkajian Dan Pengembangan Teknologi Pertanian. Bogor.

Imran, A., S. Sama, Suriany, \& D. Baco. 2003. Uji Multilokasi Beberapa Galur dan Kultivar Padi Superior Baru di Daerah Sidrap, Wajo dan Soppeng di Sulawesi Selatan. Jurnal Agrivigor 3

Makarim, A.K., U.S. Nugraha, dan U.G. Kartasasmita. 2000. Teknologi Produksi adi Sawah. Pusat Penelitian dan Pengembangan Tanaman Pangan. Bogor.

Mulyaman, 2008. Sinergisme sistem perlindungan tanaman, tantangan dan peluang penanganan opt untuk akses pasar. http://smulyaman. blogspot.com/ 2010/01/ jadwal-hari-ini-12januari-2010.html. 3 Juni 2012.

Pantjar Simatupang dan Nizwar Syafa'at, 2002 Pengembangan Potensi Sumberdaya Petani Melalui Penerapan Teknologi Partisipatif. Disampaikan Seminar Nasional Peningkatan Pendapatan Petani Melalui Penerapan Teknologi Tepat Guna 2002

Rajaguguk, Johny H., 2011. Koordinasi dan Pemberdayaan Penyuluhan Pertanian. BPTP Bengkulu

Saptana , T. Panaji, H. Tarigan dan A. Setianto. 2010. Analisis Kelembagaan pengendalian hama terpadu mendukung agribisnis kopi rakyat dalam rangka otonomi daerah Pusat Penelitian Analisis Kebijakan Pertanian, Bogor.

Setyono, A., Sutrisno, Sigit Nugraha dan Jumali. 2001. Uji coba kelompok jasa pemanen dan jasa perontok. Laporan Akhir Tahun TA. 2000. Balai Penelitian Tanaman Padi Sukamandi.

Suhartatik, E. dan R. Sismiyati. 2000. Pemanfaatan pupuk organik dan agent hayati pada padi sawah.

Sulton Mawardi Sulton Mawardi, 2004. Desentralisasi dan Pelayanan Penyuluhan Pertanian: Acuan, Transfer dan Pembangunan Kapasitas dalam Hubungan Antartingkat Pemerintahan di Indonesia." Laporan penelitian. Jakarta: SMERU.

Swastika, D.K.S., J. Wargiono, Soejitno dan A. Hasanuddin. 2007. Analisis Kebijakan Peningkatan Produksi Padi melalui Efisiensi Pemanfaatan Lahan Sawah di Indonesian. Bogor. PSEKP. 


\section{Lampiran1.}

Tabel 7. Hasil Analisis Tingkat Kepentingan dan Indeks Kepuasan Petani di Jawa Barat (n=120)

\begin{tabular}{|c|c|c|c|c|c|c|c|c|c|}
\hline Instrumen & $\begin{array}{c}\text { Skor } \\
\mathrm{Xi}\end{array}$ & Katagori Xi & $\begin{array}{c}\text { MIS } \\
\text { S }\end{array}$ & WF & Yi & $\begin{array}{c}\mathrm{MS} \\
\mathrm{S}\end{array}$ & $\begin{array}{c}\text { WS } \\
\text { I }\end{array}$ & CSI & $\begin{array}{l}\text { Katagori } \\
\text { CSI }\end{array}$ \\
\hline \multicolumn{10}{|l|}{ Penyuluhan } \\
\hline 9. Waktu Penyuluhan & 2.83 & $\begin{array}{l}\text { Cukup } \\
\text { Tinggi }\end{array}$ & 0.02 & $\begin{array}{c}0.0 \\
3\end{array}$ & $\begin{array}{c}1.4 \\
2\end{array}$ & 0.84 & $\begin{array}{c}0.0 \\
2\end{array}$ & $\begin{array}{c}0.4 \\
7\end{array}$ & $\begin{array}{l}\text { Cukup } \\
\text { Puas }\end{array}$ \\
\hline 10. Frequensi Penyuluhan & 3.41 & $\begin{array}{l}\text { Cukup } \\
\text { Tinggi }\end{array}$ & 0.03 & $\begin{array}{c}0.0 \\
3\end{array}$ & $\begin{array}{c}1.2 \\
5\end{array}$ & 0.74 & $\begin{array}{c}0.0 \\
2\end{array}$ & $\begin{array}{c}0.4 \\
9\end{array}$ & $\begin{array}{l}\text { Kurang } \\
\text { Puas }\end{array}$ \\
\hline 11. Tempat Penyuluhan & 2.67 & $\begin{array}{l}\text { Cukup } \\
\text { Tinggi }\end{array}$ & 0.02 & $\begin{array}{c}0.0 \\
3\end{array}$ & $\begin{array}{c}1.7 \\
5\end{array}$ & 1.04 & $\begin{array}{c}0.0 \\
3\end{array}$ & $\begin{array}{c}0.5 \\
4\end{array}$ & $\begin{array}{l}\text { Cukup } \\
\text { Puas }\end{array}$ \\
\hline 12. Materi sesuai kebutuhan & 2.72 & $\begin{array}{l}\text { Cukup } \\
\text { Tinggi }\end{array}$ & 0.02 & $\begin{array}{c}0.0 \\
3\end{array}$ & $\begin{array}{c}1.7 \\
5\end{array}$ & 1.04 & $\begin{array}{c}0.0 \\
3\end{array}$ & $\begin{array}{c}0.5 \\
5\end{array}$ & $\begin{array}{l}\text { Cukup } \\
\text { Puas }\end{array}$ \\
\hline 23. Alat mesin pertanian & 2.83 & $\begin{array}{l}\text { Cukup } \\
\text { Tinggi }\end{array}$ & 0.02 & $\begin{array}{c}0.0 \\
3\end{array}$ & $\begin{array}{c}1.7 \\
5\end{array}$ & 1.04 & $\begin{array}{c}0.0 \\
3\end{array}$ & $\begin{array}{c}0.5 \\
7\end{array}$ & $\begin{array}{l}\text { Cukup } \\
\text { Puas }\end{array}$ \\
\hline 24. Cara tanam & 2.70 & $\begin{array}{l}\text { Cukup } \\
\text { Tinggi }\end{array}$ & 0.02 & $\begin{array}{c}0.0 \\
3\end{array}$ & $\begin{array}{c}2.0 \\
0\end{array}$ & 1.19 & $\begin{array}{c}0.0 \\
3\end{array}$ & $\begin{array}{c}0.6 \\
3\end{array}$ & $\begin{array}{l}\text { Cukup } \\
\text { Puas }\end{array}$ \\
\hline 25. Kehilangan hasil & 3.87 & Tinggi & 0.03 & $\begin{array}{c}0.0 \\
4\end{array}$ & $\begin{array}{c}1.0 \\
0\end{array}$ & 0.60 & $\begin{array}{c}0.0 \\
2\end{array}$ & $\begin{array}{c}0.4 \\
5\end{array}$ & $\begin{array}{l}\text { Kurang } \\
\text { Puas }\end{array}$ \\
\hline $\begin{array}{l}\text { 26. Peningkatan kesuburan } \\
\text { lahan }\end{array}$ & 3.43 & Tinggi & 0.03 & $\begin{array}{c}0.0 \\
3\end{array}$ & $\begin{array}{c}1.8 \\
3\end{array}$ & 1.09 & $\begin{array}{c}0.0 \\
4\end{array}$ & $\begin{array}{c}0.7 \\
3\end{array}$ & $\begin{array}{l}\text { Cukup } \\
\text { Puas }\end{array}$ \\
\hline 27. Pemupukan berimbang & 2.55 & $\begin{array}{l}\text { Cukup } \\
\text { Tinggi }\end{array}$ & 0.02 & $\begin{array}{c}0.0 \\
2\end{array}$ & $\begin{array}{c}2.2 \\
5\end{array}$ & 1.34 & $\begin{array}{c}0.0 \\
3\end{array}$ & $\begin{array}{c}0.6 \\
7\end{array}$ & $\begin{array}{l}\text { Cukup } \\
\text { Puas }\end{array}$ \\
\hline 28. Pola tanam (IP) & 2.53 & $\begin{array}{l}\text { Cukup } \\
\text { Tinggi }\end{array}$ & 0.02 & $\begin{array}{c}0.0 \\
2\end{array}$ & $\begin{array}{c}2.0 \\
8\end{array}$ & 1.24 & $\begin{array}{c}0.0 \\
3\end{array}$ & $\begin{array}{c}0.6 \\
1\end{array}$ & Puas \\
\hline 29. Pengendalian OPT & 3.03 & $\begin{array}{l}\text { Cukup } \\
\text { Tinggi }\end{array}$ & 0.03 & $\begin{array}{c}0.0 \\
3\end{array}$ & $\begin{array}{c}2.0 \\
8\end{array}$ & 1.24 & $\begin{array}{c}0.0 \\
4\end{array}$ & $\begin{array}{c}0.7 \\
3\end{array}$ & Puas \\
\hline 30. Varietas Unggul Baru & 3.65 & Tinggi & 0.03 & $\begin{array}{c}0.0 \\
4\end{array}$ & $\begin{array}{c}1.6 \\
7\end{array}$ & 0.99 & $\begin{array}{c}0.0 \\
4\end{array}$ & $\begin{array}{c}0.7 \\
1\end{array}$ & Puas \\
\hline
\end{tabular}

Keterangan:

$\mathrm{Xi}=$ nilai kepentingan variabel faktor penentu peningkatan produksi padi $\mathrm{Y}$ ke $\mathrm{i}$.

MISS= Mean Importance Score

$\mathrm{WF}=$ Weight Factors

$\mathrm{Yi}=$ nilai kepuasan variabel faktor penentu peningkatan produksi padi $\mathrm{Y}$ ke $\mathrm{i}$.

MSS= Means Stisfaction Score

$\mathrm{WSI}=$ Weight Score

CSI $=$ Customer Satisfaction Indeks 
